Velimir Štavljanin ${ }^{1}$

Jelena Cvijović ${ }^{2}$

Milica Kostić-Stanković ${ }^{2}$
JEL: M37

DOI: 10.5937/industrija45-16065

UDC:

Original Scientific Paper

\title{
Research of indirect advertising in video game industry
}

\author{
Article history: \\ Received: 31 August 2017 \\ Sent for revision: 11 September 2017 \\ Received in revised form: 10 October 2017 \\ Accepted: 10 October 2017 \\ Available online: 25 December 2017
}

\begin{abstract}
Product placement or indirect advertising, and video games are two very current themes. There are more and more video game users in the world, and fewer are those who have confidence in traditional forms of advertising. In order to reach a larger number of consumers, product placement is increasingly used today, and product placement in video games is becoming an increasingly attractive field of action. Although there are numerous studies in the field of the application of product placement in video games, authors have so far not been concerned with studying the way different motivation for playing influences the acceptance of product placement and whether, depending on the type of motivation, the effects of product placement would be different. This will allow better targeting of video game players and increasing product placement efficiency in video games. This paper examines whether different categories of primary motivation can affect the product placement effects, and whether players' attitudes towards product placement differ, depending on the primary motivation.
\end{abstract}

Keywords: product placement, video games, player types, players' motivation

\section{Istraživanje indirektnog oglašavanja u industriji video igara}

Apstrakt: Indirektno oglašavanje $i$ video igre predstavljaju dve veoma aktuelne teme. Sve je više korisnika video igara u svetu, a sve je manje onih koji veruju u tradicionalne vidove oglašavanja. Kako bi se dosegao veći broj potrošača, danas se sve više koristi indirektno oglašavanje, pa ovaj tip

\footnotetext{
${ }^{1}$ University of Belgrade, Faculty of Organizational Sciences, velimirs@fon.bg.ac.rs

${ }^{2}$ Economics Institute

${ }^{3}$ University of Belgrade, Faculty of Organizational Sciences 
Štavljanin V. et al.: Research of indirect advertising in video game industry

oglašavanja u video igrama postaje sve atraktivnije polje delovanja. lako postoje mnogobrojne studije u oblasti primene indirektnog oglašavanja u video igrama, do sada se autori nisu bavili istraživanjem kako različita motivacija za igranje utiče na prihvatanje indirektnog oglašavanja i da li će se u zavisnosti od tipa motivacije efekti od indirektnog oglašavanja biti različiti. Ovo će omogućiti bolje ciljanje igrača video igara i povećanje efikasnosti indirektnog oglašavanja u video igrama. $U$ ovom radu se istražuje da li različite kategorije primarne motivacije mogu da utiču na efekte oglašavanja, kao i da li se, u zavisnosti od primarne motivacije, razlikuju stavovi igrača prema indirektnom oglašavanju.

Ključne reči: indirektno oglašavanje, video igre, tipovi igrača, motivacija igrača.

\section{Introduction}

Faced with contemporary, cluttered and saturated advertising environment, marketers are constantly trying to find innovative ways to reach different target groups. In recent times, various forms of product placement, which is generally defined as "the intentional, paid inclusion of products, services, brands, or/ and brand identifiers into media content" (Chen and Haley, 2014) are becoming popular and important communication tools. The great popularity of computer and video games and increasing number of their consumers makes this media attractive for product placement (Sierra and Taute, 2013). Revenues from video games have supprased revenues from Holywood in 2004 (Yi, 2004). At the global level, video game market is estimated to reach 72.5 billion U.S. dollars until the end of 2017. Worldwide spending on video games advertising reached 4.91 billion dollars in 2016, and is expected to reach 5.6 billion U.S. dollars in 2017. It will continue to grow annually, up to 6.91 billion dollars that are estimated for 2019 (Statista, 2017).

Statistical data show that at least one family member plays video games regularly in $63 \%$ of the households in USA. Among them, $59 \%$ are male and $41 \%$ female players. Unlike earlier opinion that mainly children and teenagers are video game players, data indicate that the average age of today's male players is 35 and 44 for female players (Entertainment Software Association, 2016). Therefore, it is obvious why product placement in video games is gaining popularity among marketers, considering its ability to effectively reach different target groups by incorporating the advertising messages into games (Sierra and Taute, 2013).

Video games have become mass medium suitable for reaching millions of people on the global level due to the development and constant upgrading of game technology, including 3D graphics and interactive gaming, which 
Štavljanin V. et al.: Research of indirect advertising in video game industry

stimulates the gaming experience and players' interest (Besharat et al., 2013; Terlutter and Capella, 2013). However, despite their growing popularity, video games still represent underutilized advertising medium that is yet to be developed (Poels, Janssens and Herrewijn, 2011).

Although there are numerous studies in the field of the application of product placement in video games, authors have so far not been concerned with analysing of how different motivation for playing influences the acceptance of product placement and whether, depending on the type of motivation, the effects of product placement will differ. If this influence is empirically proved, video game players can be targeted even more better, so the overall efficiency of product placement, as a form of indirect advertising, can be increased.

The paper is structured in such a way that the following section contains an overview of literature in the field of games, motivation for playing games and product placement. In the next section, the methodology and research results are presented. In conclusion, authors suggest the ways results can be used, note the limitations of the research presented in this paper and provide guidelines for future work.

\section{Theoretical background}

\subsection{Video games}

The first impressions related to video games are mostly fun and entertainment. However, games are generally attributed much more importance. Crawford (1997) noted that games represent a fundamental part of human existence. Games were of great importance for the survival of the human species through improving the survival skills and learning the importance of respecting rules (Bergeron, 2006; Koster, 2014). In the last decade, video games are being developed for using to train employees, build relationships with customers, advertise products or services, or increase experience (Ryan, Rigby and Przybylski 2006). Considering the trend of digitalization and networking in business and marketing communication (Veselinović et al., 2016), games are used in corporate environment in different contexts. Edery and Mollick (2009) note that companies today use games to revolutionize the way they interact with employees and customers.

Salen and Zimmerman (2004) define the game as a system in which players engage in an artificial conflict, defined by rules, which results in a quantifiable outcome. Adams (2010) defines the game as a type of play activity, conducted in a context of a pretended reality, in which the participant (s) try to achieve at least one arbitrary, non-trivial goal by acting in accordance with the 
Štavljanin V. et al.: Research of indirect advertising in video game industry

rules. McGonial (2011) says that playing a game is a voluntary attempt to overcome unnecessary obstacles. These, like many other definitions, are based on similar bases, which relate to the rules that must exist, to the challenges that have to be overcome, to the goals that need to be achieved and to the world of a game that has its limits. Good game (Koster, 2013) is defined as one that teaches everything it has to offer before the player stops playing.

Games can be categorized in different ways. Categorization is an important aspect to be considered when reconsidering product placement in the context of this media. Games can be categorized into (Sheldon, 2004): action, adventure, role-playing, simulations, strategy, and multiplayer. A similar categorization is illustrated by Rollings and Adams (2003) and defines games as: action, strategy, role-playing, real-world simulations, construction and management games, adventure, and puzzle games. Edery and Mollick (2009) classify games according to two dimensions. The first refers to whether the game is casual or enthusiastic, and the other relates to sociability and sets the game as a single or multi-player. Games can be: single-player enthusiastic, single-player casual, multi-player enthusiastic and multi-player casual. Each segment carries a certain potential for product placement. Single-player enthusiastic "sandbox" games are, for example, ideal for in-game advertising (Edery and Mollick 2009). Multiplayer enthusiastic is suitable for unconventional strategies. Sheldon (2004) also analyzed the possibility for mapping genres of games and identified the following genres: fantasy, science fiction, war, espionage, crime, mystery, horror, romance, and western.

Most authors agree that stories are a fundamental part of game design (Rolls and Adams, 2003; Adams, 2010; Radoff, 2011; Schell, 2015). Story represents the one extreme is the game, while the player, as the one that tells the story by the act of playing, represents the other extreme (Rollings and Adams, 2003). There are two types of product placement considering the integration into the story (Edery and Mollick, 2009): highly integrated into the gameplay experience and peripheral to game action. Higly integrated product placement campaigns are some of the most successful campaigns. For achieving highly integrated product placement, the product needs to be integrated into the story or gameplay. This requires a considerable amount of effort. In case of peripheral product placement, products are integrated into the game landscape. Except in very simple games, the story is made of separate episodes or steps (Sheldon, 2004). These steps or activities (Adams, 2010) or levels (Sheldon, 2004) are the basics of game organization. Story behaves like a frame for separate episodes (Sheldon, 2004), a mean of integration. Story integrates objects in a scene, joint player efforts (like a mission, for example) or ways players communicate between them. From previous, it can be concluded that the story is key to the integration of product 
Štavljanin V. et al.: Research of indirect advertising in video game industry

placement into the game. Stories can be linear and nonlinear. Sometimes, nonlinear story can be mistakenly equated with a linear one, because players' experience is always linear (Sheldon, 2004). But, the linear sequence is somewhat less intuitive, much more predictable and less interesting for gamers. Predictability is less creative, and stories often offer different paths to foster creativity.

\subsection{Motivations to play}

Games have been studied for decades, however, very little research is dedicated to the motivation to play (Ryan, Rigby and Przybylski, 2006), and although most authors agree that what characterizes games is their power of motivation. Motivation for playing the game is a prerequisite for understanding the behavior and interaction of players in the game environment, so the identification of the motives is of exceptional importance.

One of the widely cited approaches to the classification of patterns of player behavior is Richard Bartle's typology of player types (1996). According to this typology, there are four types of players:

- Achievers - players who are motivated by achieving goals related to the game;

- Explorers - players who are motivated by the research of the game world;

- Socializers - players who are motivated by interaction with other players;

- Killers - players who are motivated by a victory over other players.

Bartle created an updated model (Bartle 2004) in which he made a distinction between implicit and explicit player behavior. Each type of the previous model has a subtype for an implicit and subtype for an explicit dimension. For example, socializers can be classified into implicit friends and explicit networkers. Friends are players who interact with players they know and with whom they have deeper links. Networkers are players who interact with other players, even those unknown. Updated model has eight categories: opportunists, hackers, friends, griefers, planners, scientists, networkers, and politicians.

Ryan and Deci (2000a) suggested that motivation is not unitary phenomenon, and that people have different types of motivations by level and orientation of motivation. In Self-Determination Theory (SDT) distinction between types of motivations is based on different reasons or goals that affect actions. Motivation can basically be classified into intrinsic and extrinsic (Ryan and Deci 2000a). The main difference between intrinsic and extrinsic motivation (Ryan and Deci, 2000b) is that intrinsic refers to doing something because it is inherently interesting or enjoyable, while extrinsic refers to doing something 
because it leads to separable outcome. Activities that are intrinsically motivated are those people do naturaly and spontaneously in order to follow their inner interests (Deci and Ryan, 2000). Although intrinsic motivation represents innate propensity, it is neccessary to provide supportive conditions for its maintenance and enhancement. Intrinsic motivation can be improved if experienced feelings of competence during action are accompanied by a sense of autonomy (Ryan and Deci, 2000a; Ryan and Deci, 2000b). Some research results suggest that satisfaction of the need for relatedness may also be important for intrinsic motivation (Ryan and Deci 2000b). Extrinticly motivated behavior is not inherently interesting and must be externaly prompted and can vary in the extent in which it represents self-determined behavior. According to SDT, under certain conditions, these externaly prompted behaviors can become more self determined (Ryan and Deci, 2000a; Ryan and Deci, 2000b). These conditions are: sense of relatedness (belongingness and connectedness), as mainly responsible, as well as competence and authonomy. Authors Ryan, Rigby and Przybylski (2006) confirmed in their research that games, regardless of genres, possess psychological attractiveness thanks to the capacity to generate feelings of autonomy, competence and relatedness.

Author Yee $(2005 ; 2006)$ developed a model of player motivation, relying on research by Bartle (1996). In order to address the shortcomings of previous research, such as low correlation between components, overlapping of components and no practical way to assess users, Yee created a model based on empirical research. By using factor analytical approach, Yee identified three overarching nonexclusive motives. These three components are: achivement, social, and immersion. The component „achievement"refers to satisfaction in continuous advancement, in analyzing and understanding game mechanics and in challenging and competing with others. The second component refers to the pleasure of meeting and getting acquainted other players, relation to other players and working together and cooperation with others. The "immersion“component refers to the pleasure in exploring the world of games, in role playing, in the customization of character appearance, and escapism from the real world.

\subsection{Types of product placement in computer and video games}

Product placement is a set of instruments used by advertisers for easier reaching the target group, and it involves incorporating brands or their elements into different media formats for commercial reasons (Lowrey, et al., 2005). Advertisers have embarked on the development and implementation of innovative advertising instruments that include the incorporation of brands, products and / or some of their features into various media content (movies, series, TV shows, radio shows, video games, music videos and books) in 
Štavljanin V. et al.: Research of indirect advertising in video game industry

order to achieved the desired influence on the perception, attitudes and behavior of the target group. The main advantage of these advertising tools reflects in overcoming the problems that arise in connection with traditional advertising instruments (Küster et al., 2010).

There are three main types of product placement in computer and video games: advertising in social network games, in-game advertising and advergames. Each of the types possesses specific characteristics, and all three are considered to be effective promotional tools.

Social network games are online communities in which players can interact and play games with others (Rozendaal et al. 2013). Product placement in social network games represents "placement of brands or products in games that are played via social networks" (Terlutter and Capella, 2013). The increasing popularity of social games and rising number of social network users at the global level motivates advertisers to embed indirect advertising messages in this medium (Vanwesenbeeck, Walrave and Ponnet, 2013; Chen and Haley, 2014).

In-game advertising considers embedding of products and corporate brands within computer or video games. There are two types of in-game advertising. Static ads are fixed in the game and cannot be lately removed. This characteristic represents the major disadvantage of static ads (Terlutter and Capella, 2013). Dynamic ads are replaceable and, therefore, able to convey up-to-date information. They allow the incorporation of new advertising messages, which prevents obsolescence of advertisements (Nelson, 2002).

Advergames are designed for the special purposes of promoting certain brands or products. As Terlutter and Capella (2013) noted, their major advantages are: short time necessary for playing, possibility to play during breaks, effectiveness as advertising tool and ubiquity; however, they are sometimes criticized for unethical nature since many are designed for promotion of unhealthy products.

\subsection{The effectiveness of product placement in computer and video games}

There is a growing body of evidence of product placement effectiveness in computer and video games. Authors mainly support the attitude that a significant percentage of game players are able to recall ads they saw during the play. In the earlier research, Nelson (2002) found out that players recalled between $25 \%$ and $30 \%$ of advertised brands immediately after finishing the game, and $10 \%$ to $15 \%$ after five months. Research results show that game players are actually able to subconsciously notice background advertisements, although they may not be able to explicitly recall them 
Štavljanin V. et al.: Research of indirect advertising in video game industry

afterwards. This is especially notable for brands for which players have previous favorable attitudes, so they automatically stimulate further elaboration (Gangadharbatla, Bradley and Wise, 2013). Therefore, empirical findings indicate that players actually have explicit and implicit memory of advertisements, despite the concentration put on playing games (Yeu et al., 2013).

Some of the main advantages of this type of product placement are: interactivity, experiential nature of video games and players' engagement (Sierra and Taute, 2013) and the ability of personalization (Kwak et al., 2010). Actually, research on video game product placement effectiveness have shown that interactivity encourage better memorization of advertising messages (Jeong et al., 2011). Certainly, memorization is also enhanced with longer durability of product placement in relation of traditional advertising which may significantly prolong the period of consumers' exposure to advertising. The difference in information processing between product placement and traditional forms of advertising occurs due to a lower likability of ad skepticism activation in case of product placement since its commercial function is less obvious (Obermiller, Spangenberg and MacLachlan, 2005). This happens due to the fact that players willingly participate in entertainment content, which is in the focus of their attention, so receiving advertising information comes simultaneously (Grigorovich and Constantin, 2004). The research of Tikkanen et al. (2009) showed that players are likely to remember indirectly advertised brands even though they are aware of commercial intentions, which implies that their knowledge of persuasive intention did not counteract advertising effects.

There are also some opposite opinions imposing that interactive features of video games may reduce the perceptive possibilities of players because their attention is divided between visual perception and controlling the game (Duff and Faber, 2011). Shapiro and Krishnan (2008) found out that placements are less likely to be remembered when players' attention is divided between visualization of displayed brands and listening to unrelated sounds. Auditory distractions restrict implicit brand memory retrieval, while visual distractions cause no such effect. A bit higher distraction effects on implicit memory appear when it comes to familiar brands, while, on the other hand, unfamiliar brands bring more attention which annuls sensory distraction (Choi et al., 2013). Chaney, Lin and Chaney (2004) found out that, in case of first-person shooting games, players could remember seeing virtual billboards in the game, but were not able to recall most of brands or product categories displayed on billboards which could be explained with interactive nature of video games that affects the ability of players to perceive advertising messages. But, as Yang et al. (2006) noted, it should be considered that product placement in interactive video games generates effects not only on explicit, but also on implicit memory, which indicates that even though players 
Štavljanin V. et al.: Research of indirect advertising in video game industry

could not explicitly recall brands embedded in video games, they store that information in implicit memory and can use it in future when making purchasing decisions.

Product placement significantly contributes to the enhancement of the reality of the game. Players' experiential experience becomes more realistic due to the improved technology of video games which enables highly realistic simulations of advertised products. Nelson, Keum and Yaros (2004) found out in their research that, from players' perspective, the degree of reality of sport games is considerably dependent on brands that are incorporated in the game. On the other hand, there is an additional possibility for enhancement of product placement effectiveness when players identify with famous sportsmen that appear in the game, who are associated with advertised brands.

Furthermore, research results have shown mainly positive attitudes of players towards product placement in video games (Nelson, 2002). However, the probability of brand recall and positive attitudes towards advertised brands depends on the modality of advertisement. Research has shown that verbal and audio-visual forms and more easily remembered than solely visual form which means that more prominent placements are better remembered than subtly displayed ones (Grigorovich and Constantin, 2004). On the other hand, players' attitudes are more positive when product placements are not interruptive and impeding, when they are relevant to the game theme and not too deliberate (Chen and Haley, 2014). Therefore, attitudes are more favorable when placements are not too intrusive. Also, both recall and attitudes are better when game and product placement are congruent, as it enhances players' positive gaming experience (Peters and Leshner, 2013).

A connection between game outcome and brand attitudes has also been detected. It was shown that game success influences product placement, so, after playing the game, winners evaluate both, the game and advertised brands, more favorably than before beginning (Mau, Silberer and Gödecke, 2010; Steffen, Mau and Schramm-Klein, 2013). Violent content of many video games that evoke an aggressive mindset of players, may adversely affect the image of advertised brands. As Jeong et al. (2011) noted, even though violent scenes influence brand logo memory through engagement and may cause change of attitudes via psychological arousal, it appears that placement of ads in violent games does not lead to desired effects.

\section{Research methodology}

In the paper, an empirical research on the sample of video game players was conducted in order to answer the following research questions: 
Štavljanin V. et al.: Research of indirect advertising in video game industry

- Are there any differences and what are the differences in the memory level of brands that are advertised in video games in relation to the primary motive for playing video games?

- Are there differences in players' attitudes towards product placement in relation to the primary motive for playing video games?

\section{Procedure}

The research involved players of a commercial sports soccer simulation game in which the character is activated through game-pad controls on game consoles or through a mouse and/or keyboard on a PC platform. Participants were recruited by placing an invitation to survey on a game comuity online forum and by personal contact with gamers in playing centers. Participants were asked to fill out a questionnaire regarding their experience with particular soccer simulation game. The questionnaire was divided into four sections. The first section included questions about the experience of the respondents in the gameplay, following by the section with questions about the type of motivation for the game, and the last two sections containing questions about recall and recognition of the brands displayed in the game and questions about attitudes towards product placement.

\section{Used game}

A commercial sports soccer simulation was selected for research. The sports game was chosen due to the fact that it is most suitable for in-game placement (Nelson 2002). Bilboards with brands in field sports games add realism to the game (Chaney, Lin, and Chaney, 2004). The reasons for choosing the soccer simulation are (Yang, Ewoldsen, Dinu, and Arpan 2006): brand placements are easy-to-see, the nature of placements ensures that all players, regardless of their playing skills see placements, and relatively simply playing controls. All 37 brand placements were visual, either as bilboards or signage on the field or signage on player dreses.

\section{Participants}

There were 86 gamers, participants in this study. Before proceeding with statistical analysis, eight cases were excluded from the data set due to a large number of missing values and because of failure to demonstrate serious response. After exclusion, the total number of cases included in the analysis was 78 . Out of the remaining participants, $100 \%$ (78) were men between 18 and 43 years old. Table 1 shows age structure.

Most of the participants are regular game players. In $16.7 \%$ of cases, they play video games every day, and $37.2 \%$ play video games from 3 to 6 times a week. This coincides with the research that $15 \%$ of gamers are "hardcore" gamers (Griffihs, 2003). 
Štavljanin V. et al.: Research of indirect advertising in video game industry

Table 1. Age structure of participants

\begin{tabular}{|l|l|l|}
\hline Age & Participants (\%) & Cumulative \% (\%) \\
\hline$<=20$ & 6,5 & 6,5 \\
\hline $21-25$ & 21,6 & 28.1 \\
\hline $26-30$ & 27 & 55.1 \\
\hline $31-35$ & 32 & 87.1 \\
\hline $36-40$ & 10.3 & 97.4 \\
\hline$>40$ & 2.6 & 100 \\
\hline
\end{tabular}

Source: Review authors

More than $50 \%$ of players play intensively more than three times a week. Table 2 shows detailed information about the frequency of playing video games. Details of the frequency of playing a specific video game that was used as a stimulus in the study is given in Table 3.

Table 2. The frequency of playing video games

\begin{tabular}{|l|l|l|}
\hline Frequency of playing & Participants (\%) & Cumulative \% (\%) \\
\hline Every day & 16.7 & 16.7 \\
\hline 3 to 6 time per week & 37.2 & 53.9 \\
\hline 1 to 2 times a week & 15.4 & 69.3 \\
\hline Less than that & 30.7 & 100.0 \\
\hline
\end{tabular}

Source: Review authors

Table 3. The frequency of playing video games used in the research

\begin{tabular}{|l|l|l|}
\hline Frequency of playing & Participants (\%) & Cumulative \% (\%) \\
\hline Every day & 9.0 & 9.0 \\
\hline 3 to 6 times a week & 8.9 & 17.9 \\
\hline 1 to 2 times a week & 25.6 & 43.5 \\
\hline Less than that & 56.5 & 100.0 \\
\hline
\end{tabular}

Source: Review authors

\section{Measures}

Player motivation. Player motivation was measured using a scale developed by Yee $(2005 ; 2006)$. This scale was chosen as a first oprerationalized scale and one of the few scales that measure player motivation. The scale measures three components of playes motivation (achievement, social, and immersion) using 39 items. The score for the achievement component was obtained by calculating the mean of 14 items representing this component (Crombach's $\alpha=.78$ ). The score for the social component was obtained by calculating the mean of 11 items (Crombach's $\alpha=.73$ ). The score for the immersion component was obtained by calculating the mean of 14 items 
representing immersion (Crombach's $\alpha=.78$ ). In this study, only primary motivation was analyzed.

Explicit memory test. Explicit memory was measured using a recognition and unaided recall tasks. For the recognition task, the participants were given 37 brand names that appear in the game and 37 brand names that were not presented in the game. The total number of brands presented for recognition was 74.

At the end, within the fourth segment of the second phase of the research, the participants were asked to evaluate certain statements on the Likert scale of one to five, while 1 meant "I completely disagree" and 5 "I completely agree“. The objective of this segment of the questionnaire was to evaluate players' attitudes regarding product placement in video games, especially in relation to traditional advertising and its effects.

\section{Results}

Participants in the research expressed different primary motives for the game. The primary motive for 28 players $(35.9 \%)$ was achievement. For majority of players $(n=34 ; 43.6 \%)$, socialization was the primary motive. The smallest number, 16 of players $(20.5 \%)$ was motivated by immersion.

Figure 1 Frequency of brand recalls

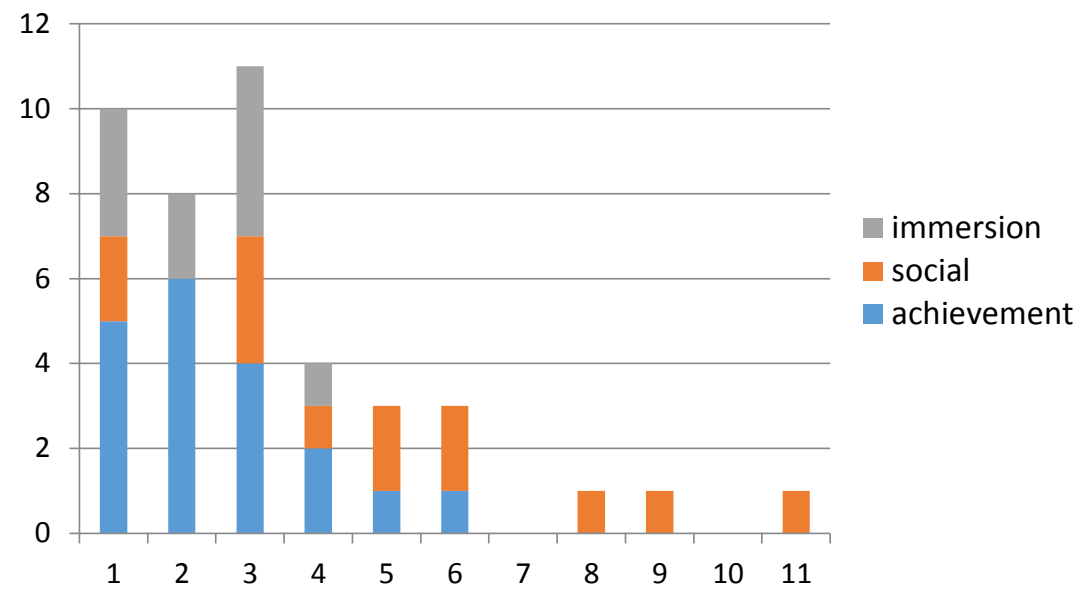

When tested for unaided recall, 36 players $(46.2 \%)$ did not manage to recall any brand from the game, and in 42 cases (53.8\%) they managed to 
remember at least one brand. Those who remembered brands, managed to recall from one to 11 brands of 37 that appeared in the game. Figure 1 shows the frequency of brand recalls by players. Participants also recalled brands that they have not seen in the game. In the group where achievement is the primary motive, the percentage of those who recalled a brand was $67.9 \%$, while $32.1 \%$ did not managed to recall any brand. In the group of those whose motive is social, the percentage of those who remembered a brand was $38.2 \%$, while $61.8 \%$ did not recall any brand. In the group motivated by the immersion, percentage of those who remembered a brand was $62.5 \%$, and $37.5 \%$ did not remember any brand at all.

Brand recall was subjected to chi-square to determine whether there was an association between recall and primary motivation category. A chi-square test indicated significant association between brand recall and primary motivation category $\mathrm{x} 2(2.78)=6.028, p=.049$. Figure 2 shows brand recall in relation to different primary motives.

Figure 2 Recall of placed brands by primary motive categories

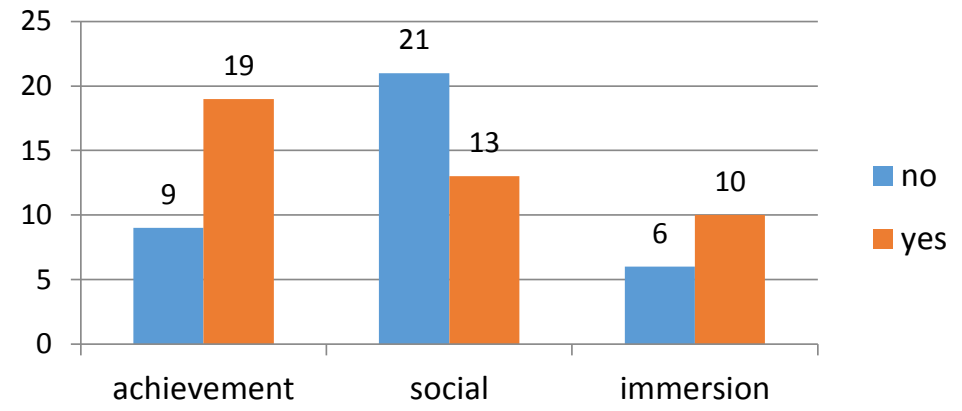

Almost all participants recognized at least one brand in the recognition section of the questionnaire. Only one participant did not recognize any brand. Participants recognized from one to 21 brands out of 37 brands. In relation to the recall test, $268 \%$ more brands were recognized. Figure 3 shows the frequency of brand recognition by players. To determine whether there was an association between brand recognition and primary motivation category, chi-square analysis was performed.

Participants were categorized as "low recognition" and "high recognition". "Low recognition" participants recognized five or fewer brands. "High recognition" participants recognized more than five brands. A chi-square test indicated no significant association $\times 2(2.78)=0.043, p=.979$. Figure 4 shows the level of recognition in relation to different primary motives. 
Štavljanin V. et al.: Research of indirect advertising in video game industry

Figure 3 Frequency of brand recognition

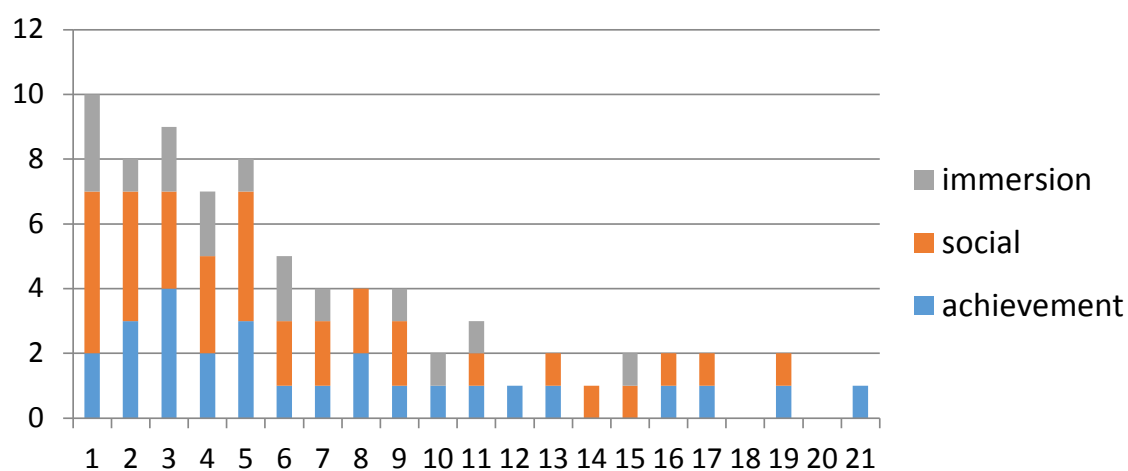

Figure 4 Recognition of placed brands by primary motive categories

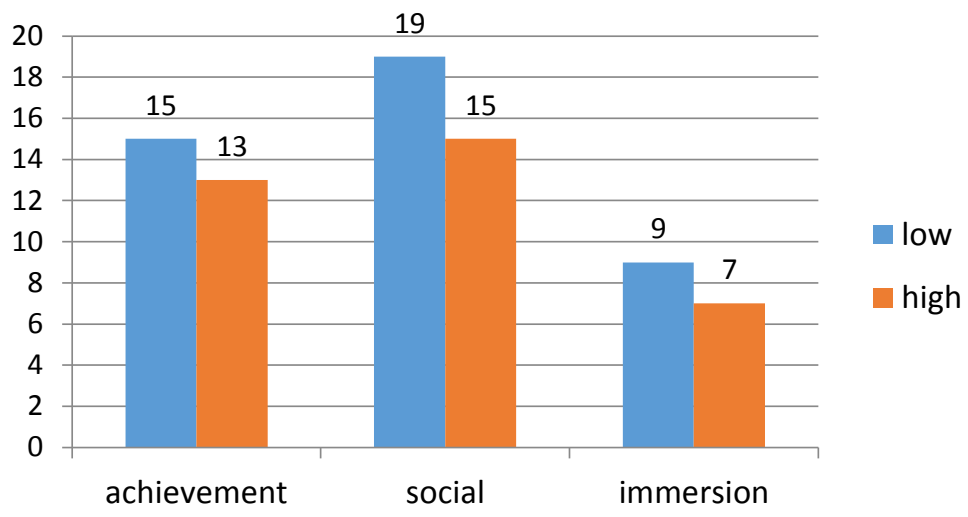

In order to answer the second research question, the participants gave evaluated given statements to determine whether there were differences in their attitudes resulting from the different primary player's motive. A KruskalWallis test revealed no statistically significant difference in attitudes whether the appearance of brands in video games does not disturb players, in relation to different primary motives for the game. However, a Kruskal-Wallis test revealed a statistically significant differences in players' attitudes towards statements that placed brands in video games are not considered to be "disguised" advertisements across three different primary motive categories ( $\mathrm{n}$ $=28$ : achievement, $n=34$ : social, $n=16$ : immersion), $x 2(2, n=78)=16.46$, $\mathrm{p}=.000$. The group social recorded a higher median score $(\mathrm{Md}=3.50)$ than the other two motive groups, which recorded median values of 2.00 
Štavljanin V. et al.: Research of indirect advertising in video game industry

(achievement) and 3.00 (immersion). Testing revealed no statistically significant difference in the statement that the appearance of brands in video games contributes to the realism of the action.

Furthermore, a Kruskal-Wallis test revealed a statistically significant difference in the statement that players consider displaying brands in video games to be a good alternative to traditional advertising across three different player primary motive categories, $\mathrm{x} 2(2, \mathrm{n}=78)=12.86, \mathrm{p}=.002$. The group "achievement" recorded a higher median score $(\mathrm{Md}=4.00)$ than the other two motive groups, which recorded median values of 3.50 (social) and 3.00 (immersion). Testing revealed no statistically significant difference in the statement that players do not mind that advertisers pay game producers to integrate their brand into game plot, across three different player primary motive categories. Testing revealed a statistically significant difference in the statement that players do not consider it unethical to influence players this way to purchase a particular brand across three different player primary motive categories, $\mathrm{x} 2(2, \mathrm{n}=78)=12.03, \mathrm{p}=.002$. The group "social" recorded higher median score $(\mathrm{Md}=4.00)$ than the other two motive groups, which both recorded median values of 3.00 (achievement and immersion).

Testing revealed no statistically significant difference in the statement that brands that appear in games do not draw players' attention in relation to three different player primary motive categories. Testing revealed a statistically significant difference in the statement that players prefer when the brand is discreetly placed in the background of the scene across three different players of primary motive categories, $x 2(2, n=78)=9.02, p=.011$. The group „immersion“ recorded a higher median score $(\mathrm{Md}=4.50)$ than the other two motive groups, which both recorded median values of 4.00 (achievement and social).

A Kruskal-Wallis test revealed a statistically significant difference in the statement that players consider placing brands in games as a good alternative to traditional advertising across three different player primary motive categories, $x^{2}(2, n=78)=9.57, p=.008$. The group with social motives recorded a higher median score $(\mathrm{Md}=3.00)$ than the other two motive groups, which recorded median values of 2.00 (achievement) and 1.50 (immersion). Testing revealed a statistically significant difference in the statement that players develop a desire to try a particular brand after it appears in a favorite game across three different player primary motive categories, $x 2(2, n=78)=6.06, p=.048$. The group with social motives again recorded a higher median score $(\mathrm{Md}=2.50)$ than the other two motive groups, which recorded median values of 2.00 (achievement) and 1.50 (immersion). 
Štavljanin V. et al.: Research of indirect advertising in video game industry

\section{Discussion}

An empirical study has shown that players can be classified according to primary motivation and that, depending on the primary motivation, unaided recall of the brands that are placed in video games will be different. It was shown that the group whose primary motivation is achievement and which is focused on satisfaction in continuous advancement, in the analysis and understanding of game mechanics and in challenging and competiting with others, has the highest percentage of recalling of one or more brands they saw in the game $(67.9 \%)$ compared to those who did not remember any brand $(32.1 \%)$. On the other hand, the smallest percentage of participants driven by social motives, who enjoy meeting other players, developing relations with other players and cooperating with others, recalled at least one brand $(38.2 \%)$, compared to percentage of those who did not managed to recall any brand $(61.8 \%)$. Recognition was much more successful than recall, since the number of brand recognitions has increased almost three times in comparison to the number of brand recalls. Testing did not show that there was a statistically significant difference in recognizing brands relative to the primary motivation category when observing a high and low degree of recognition. The limit of low and high recognition was the number of recognizing the closest to 50 cumulative percent.

Certain attitudes towards product placement differed in accordance with the primary motivation of the players. Among the groups of players, there were different attitudes regarding: not observing product placement in video games as "disguised" advertising, considering placed brands in games as a good alternative to traditional advertising, not considering intentions to influence players to purchase a particular brand this way to be unethical, liking when the brand is discreetly placed in the background of the scene and desire to try a particular brand after it appears in players' favorite game. The group with social motives varied in the largest number of cases and had the highest median score compared to other groups. Attitudes that did not differ among groups concerned that players did not mind the appearance of brands in video games, that the appearance of brands in video games contributes to realism of the game, that players do not mind the fact that companies pay game producers to integrate their brand into the game and that players are not being distracted by brands which appear in video games.

\section{Conclusions}

The research has confirmed that, depending on the motivation of players, the effects of the product placement can give different results. The group whose 
Štavljanin V. et al.: Research of indirect advertising in video game industry

primary motivation was social, have achieved a higher percentage of brand recalls compared to groups whose had achievement and immersion as the primary categories of motivation. So far, a significant number of authors in the field of video game development have pointed out that it is necessary to pay attention to the fact that there are different types of players and that the typology should be used in the choice of elements of video games. The results of this paper suggest that it is possible to use the typology of motivation in order to make a different schedule of product placements for different types of players, with the goal to use the game space and story best, to increase the product placement efficiency. An important aspect of the research is also the confirmation that different groups have a different attitudes towards the product placement in video games. This result can be used to balance differences in attitudes, but also to improve adverse attitudes to different video game strategies. An important fact may be that a group whose primary motivation is social, has had the most favorable attitude towards a product placement.

The research also has a number of limitations. One of the limitations of the survey is the inequality of the sample by gender. In the survey, the sample considered entirely of male players. However, in research and studies (Entertainment Software Association, 2016) it has been found that the female population plays video games to a large extent. One of the research limitations was the questionnaire used in the research that was created in the MMORPG (Massively-Multiplayer Online Role-Playing Games). There are other instruments to explore the motivation of players that are created as independent of a particular type of game (Ryan, Rigby and Przybylski 2006). The third limitation may relate to the use of the game in which 37 brands appear for the research, which is far more than it was the case in other studies (Chaney, Lin, Chaney, 2004; Yang, Roskos-Ewoldsen, Dinu, Arpan, 2006). It should also be taken into account that the research was not conducted under controlled conditions and that a large number of players have a longer experience in playing the game used in the research.

Future research should eliminate the limitations of this research, referring to the gender structure of the sample, the number of brands in video games, and controlling the research conditions. Future research should consider involving factors such as experience, which is also related to product placement. Additionally, other types of games should be included in future research to confirm that the product placement effects will be different depending on the motivation for the game. In addition to visual placement, future research may also include verbal placements. In different games, the influence of the place where the brand is placed can also be explored. One of the options that can be included in future research, is a division to passive and active placements. 
Štavljanin V. et al.: Research of indirect advertising in video game industry

\section{References}

Adams, E. (2010). Fundamentals Of Game Design. Berkeley, CA: New Riders Publishing. 2nd edition.

Bartle, R. (1996). Hearts, Clubs, Diamonds, Spades: Players Who Suit MUDs. http://www.mud.co.uk/richard/hcds.htm.

Bartle, R. (2004). Designing Virtual Worlds. Berkeley, CA: New Riders Publishing.

Besharat, A., Kumar, A., Lax, J.R., \& Rydzik, E.J. (2013). Leveraging Virtual Attribute Experience in Video Games to Improve Brand Recall and Learning. Journal of Advertising, 42(2-3), 170-182. doi:10.1080/00913367.2013.774593

Chaney, I.M., Lin, K., \& Chaney, J. (2004). The Effect of Billboards within the Gaming Environment. Journal of Interactive Advertising, 5(1), 37-45. doi:10.1080/15252019.2004.10722092

Chen, H., \& Haley, E. (2014). Product Placement in Social Games: Consumer Experiences in China. Journal of Advertising, 43(3), 286-295. doi:10.1080/00913367.2013.858086

Choi, Y.K., Lee, S.m., \& Li, H. (2013). Audio and Visual Distractions and Implicit Brand Memory: A Study of Video Game Players. Journal of Advertising, 42(2-3), 219-227. doi:10.1080/00913367.2013.775798

Crawford, C. (1997). The Art of Computer Game Design. London: Pearson Education Limited.

Deci, E.L., \& Ryan, R.M. (2000). The "what" and "why" of goal pursuits: Human needs and the self-determination of behavior. Psychological Inquiry, 227-268; 11.

Duff, B.R.L., \& Faber, R.J. (2011). Missing the Mark: Advertising Avoidance and the Distractor Devaluation. Journal of Advertising, 40(2), 51-62. doi:10.2753/joa00913367400204

Edery, D., \& Mollick, E. (2009). Changing the Game. Upper Sadle River, NJ: FT Press.

-Entertainment Software Association. (2016). The Essential Facts About the Computer and Video Game Industry.

Gangadharbatla, H., Bradley, S., \& Wise, W. (2013). Psychophysiological Responses to Background Brand Placements in Video Games. Journal of Advertising, 42(2-3), 251-263. doi:10.1080/00913367.2013.775800

Grigorovici, D.M., \& Constantin, C.D. (2004). Experiencing Interactive Advertising beyond Rich Media: Impacts of Ad Type and Presence On Brand Effectiveness in 3D Gaming Immersive Virtual Environments. Journal of Interactive Advertising, 5(1), 22-36. doi:10.1080/15252019.2004.10722091

Jeong, E.J., Bohil, C.J., \& Biocca, F.A. (2011). Brand Logo Placements in Violent Games. Journal of Advertising, 40(3), 59-72. doi:10.2753/joa0091-3367400305

Effects of Violence Cues on Memory and Attitude Through Arousal and Presence. Journal of Advertising, 59-72; 40, 3.

Koster, R. (2013). Theory of Fun for Game Design. Boston, MA: O'Reilly Media.

Küster, I., Pardo, E., \& Suemanotham, T. (2010). Product placement in video games as a marketing strategy: An attempt to analysis in Disney company. Spain: Instituto Valenciano de Investigaciones Económicas.

Kwak, D.H., Clavio, G.E., Eagleman, A.N., \& Kim, K.T. (2010). Exploring the Antecedents and Consequences of Personalizing Sport Video Game Experiences. Sport Marketing Quarterly, 19(4); 217-225. 
Štavljanin V. et al.: Research of indirect advertising in video game industry

Lowrey, T.M., Shrum, L.J., \& Mccarty, J.A. (2005). The future of television advertising. In A.J. Kimmel (Ed.), Marketing communication: Emerging trends and developments. New York: Oxford University Press. pp. 113-132.

Mau, G., Silberer, G., \& Gödecke, J. (2010). Game Outcome and In-Game Advertising Effects. In R. Terlutter, S. Diehl, \& S. Okazaki (Eds.), Advances in Advertising Research. (pp. 159-170). Wiesbaden: Springer Nature. (Vol. 1); 159-170. doi:10.1007/978-3-8349-6006-1_11

McGonigal, J. (2011). Reality Is Broken: Why Games Make Us Better and How They Can Change the World. New York, NY, USA: The Penguin Press.

Nelson, M.R. (2002). Recall of Brand Placements in Computer/Video Games. Journal of Advertising Research, 42(2), 80-92. doi:10.2501/jar-42-2-80-92

Nelson, M.R., Keum, H., \& Yaros, R.A. (2004). Advertainment or Adcreep Game Players' Attitudes toward Advertising and Product Placements in Computer Games. Journal of Interactive Advertising, 5(1), 3-21. doi:10.1080/15252019.2004.10722090

Obermiller, C., Spangenberg, E., \& MacLachlan, D.L. (2005). Ad Skepticism: The Consequences of Disbelief. Journal of Advertising, 34(3), 7-17. doi:10.1080/00913367.2005.10639199

Peters, S., \& Leshner, G. (2013). Get in the Game: The Effects of Game-Product Congruity and Product Placement Proximity on Game Players' Processing of Brands Embedded in Advergames. Journal of Advertising, 42(2-3), 113-130. doi:10.1080/00913367.2013.774584

Poels, K., Janssens, W., \& Herrewijn, L. (2013). Play Buddies or Space Invaders? Players' Attitudes Toward In-Game Advertising. Journal of Advertising, 42(2-3), 204-218. doi:10.1080/00913367.2013.774600

Prügl, R., \& Schreier, M. (2006). Learning from leading-edge customers at The Sims: opening up the innovation process using toolkits. $R$ and $D$ Management, 36(3), 237-250. doi:10.1111/j.1467-9310.2006.00433.x

Radoff, J. (2011). Game On: Energize Your Business with Social Media Games. Indianapolis, IN, USA: Wiley Publishing Inc..

Rollings, A., \& Adams, E. (2003). Andrew Rollings and Ernest Adams on Game Design. Berkeley, CA: New Riders Publishing.

Rozendaal, E., Slot, N., van Reijmersdal, E.A., \& Buijzen, M. (2013). Children's Responses to Advertising in Social Games. Journal of Advertising, 42(2-3), 142154. doi: $10.1080 / 00913367.2013 .774588$

Ryan, R.M., \& Deci, E.L. (2000). Self-determination theory and the facilitation of intrinsic motivation, social development, and well-being. American Psychologist, 55(1), 68-78. doi:10.1037//0003-066x.55.1.68

Ryan, R.M., Rigby, C.S., \& Przybylski, A. (2006). The Motivational Pull of Video Games: A Self-Determination Theory Approach. Motivation and Emotion, 30(4), 344-360. doi:10.1007/s11031-006-9051-8

Ryan, R.M., \& Deci, E.L. (2000). Intrinsic and Extrinsic Motivations: Classic Definitions and New Directions. Contemporary Educational Psychology, 25(1), 54-67. doi:10.1006/ceps.1999.1020

Salen, K., \& Zimmerman, E. (2004). Rules of Play: Game Design Fundamentals. Cambridge, MA: MIT Press.

Schell, J. (2015). The Art of Game Design: A Book of Lenses. Boca Raton, FL, USA: CRC Press - Taylor \& Francis Group. 2nd ed. 
Štavljanin V. et al.: Research of indirect advertising in video game industry

Shapiro, S., \& Krishnan, H.S. (2001). Memory-Based Measures for Assessing Advertising Effects: A Comparison of Explicit and Implicit Memory Effects. Journal of Advertising, 30(3), 1-13. doi:10.1080/00913367.2001.10673641

Sheldon, L. (2004). Character Development and Storytelling for Games. Boston, MA: Thomson Course Technology PTR.

Statista, (2017). Global Video Games Advertising Revenue. Available at: https: //www.statista.com/statistics/238140/global-video-games-advertising-revenue/..

Steffen, C., Mau, G., \& Schramm-Klein, H. (2013). Who Is the Loser When I Lose the Game? Does Losing an Advergame Have a Negative Impact on the Perception of the Brand?. Journal of Advertising, 42(2-3), 183-195. doi:10.1080/00913367.2013.774598

Terlutter, R., \& Capella, M.L. (2013). The Gamification of Advertising: Analysis and Research Directions of In-Game Advertising, Advergames, and Advertising in Social Network Games. Journal of Advertising, 42(2-3), 95-112. doi:10.1080/00913367.2013.774610

Tikkanen, H., Hietanen, J., Henttonen, T., \& Rokka, J. (2009). Exploring virtual worlds: success factors in virtual world marketing. Management Decision, 47(8), 13571381. doi:10.1108/00251740910984596

Vanwesenbeeck, I., Walrave, M., \& Ponnet, K. (2016). Young Adolescents and Advertising on Social Network Games: A Structural Equation Model of Perceived Parental Media Mediation, Advertising Literacy, and Behavioral Intention. Journal of Advertising, 45(2), 183-197. doi:10.1080/00913367.2015.1123125

Veselinović, T., Vlastelica-Bakić, T., Cicvarić-Kostić, S. (2016). Is there a correlation between organizational features and digital communication usage? Industrija, 44(3), 41-60.

Yang, M., Roskos-Ewoldsen, D.R., Dinu, L., \& Arpan, L.M. (2006). The Effectiveness of 'In-Game' Advertising: Comparing College Students' Explicit and Implicit Memory for Brand Names. Journal of Advertising, 35(4); 143-152.

Yee, N. (2005). Motivations of Play in MMORPGs: Proceedings of DiGRA 2005 Conference: Changing Views - Worlds in Play. DIGRA 2005, Vancouver.

Yee, N. (2006). Motivations for Play in Online Games. CyberPsychology \& Behavior: The Impact of The Internet, Multimedia And Virtual Reality On Behavior And Society, 9(6), 772-775. doi:10.1089/cpb.2006.9.772

Yeu, M., Yoon, H., Taylor, C.R., \& Lee, D. (2013). Are Banner Advertisements in Online Games Effective?. Journal of Advertising, 42(2-3), 241-250. doi:10.1080/00913367.2013.774604

Yi, M. (2004). They got game: Stacks of new releases for hungry video enthusiasts mean its boom time for an industry now even bigger than Hollywood. San Francisco Chronicle, http://www.sfgate.com/news/article/THEY-GOT-GAMEStacks-of-new-releases-for-hungry-2663371.php..

Zichermann, G., \& Cunningham, C. (2011). Gamification by Design Implementing Game Mechanics in Web and Mobile Apps. Sebastopol, CA: O'Reilly Media Inc..

Zichermann, G., \& Linder, J. (2010). Game-Based Marketing: Inspire Customer Loyalty Through Rewards, Challenges, and Contests. Hoboken, NJ: John Wiley and Sons. 